\title{
Terrorism and Global Security: The Case of Al- Shabaab, 2015-2018
}

\section{Davies Otonye Llewellyn \& Kenneth Nweke, Ph.D}

\author{
Department of Political Science, \\ Ignatius Ajuru University of Education, \\ Rumuolumeni, P.M.B. 5047, Port Harcourt, \\ Rivers State, Nigeria \\ Emails: otonsd@yahoo.co.uk; kenneth.nweke@iaue.edu.ng
}

$\mathrm{DOI}<10.26821 / \mathrm{IJSRC}$.8.3.2020.8312>

\begin{abstract}
Terrorism is a key issue in contemporary global security.Global security also called Internationalsecurity, is the measures taken by states and international organisations, such as the United Nations, European Union, and others, to ensure mutual survival and safety. There have been several attempts atunderstanding terrorism, in terms of motivation and implications.Indeed,Africa has had its share of terrorism and terrorsistorganisations. The studysought to determine and documentthe nature, instances, motivations for and implications of Al-Shabaab's terroristactivities Somalia and other neighboring African countries with a view to recommending possible solutions to the eradication of the age-long menace. The studyexamined the origins of Al-Shabaab, its objectives,attack trends, economic and security consequences.It adopted the Social Identity Theory as its analytical framework. The theory basically explainedthe origin andformation of Al-Shabaab and its terrorist activities. It explained how shared interests lead to association and group formation, which is an important source of pride and self-esteem. It further asserted that groups give a sense of social identity and members of an in-group will work against members of the out-group based onthe group's ideological positioning and responsesto perceived/real frustration of its abjectives. Secondary sources of data featured prominently in this study as literature- based analysis was adopted to analyse the data. The study concluded that Al-shabaab's activities have had negative impacts on the security and economies of Somalia and other neigbouringAfrican countries.As long as Al-Shabaabremains a viable threat to the security of Somalia and other neighbouring African countries, the study, therefore, recommended that stern measures be taken at a trans-national level to deploy intelligence sharing among security organisations across borders with a view to tackling the rising tide of $\mathrm{Al}$ Shabaab'sterrororist activities in the region. Constructive engagements with the populace in the region to dissuade participation in terrorist activities have become imperative.Real injustices need to be addressed where they exist and religious extremismcurtailed and eliminated through advocacies, arms control legislations, enforcements and international collaborations to trace and block sources of funds for terrorist organisations like the Al-Shabaab.
\end{abstract}

Keywords: Terrorism, Terrorists, National Security, Al-Shabaab 
Volume 8 Issue 3 March 2020

\section{Introduction}

\subsection{Background to the Study}

The impact of terrorism is phenomenal. Through whatever lenses one views the phenomenon of terrorism and, no matter how tainted by biases that view may be, there is common agreement that terrorism causes damage physically, emotionally, psychologically and materially on the direct victims and those who share in their story.

One of the poignant challenges in the global system today is the issue of Terrorism. From the market woman in a Kenyan village, through the hawker on the streets of Ethiopia, the city dwellers in Mogadishu -Somalia, the corporate leaders in the business centres of the world, diplomats in their daily line of duty, security forces and national leaders, Heads of State, Presidents and Prime Ministers have in one way or the other or at one time or the other had cause to worry about terrorism.

Contemporary Global security challengesemanate from several sources such as wars, famine, natural disasters, intra and international conflicts, inequalities in resource allocation, the policies and practices of leaders, nations and their foreign policies, but one threat that has assumed a frightening dimension in contemporary global security is Terrorists and acts of Terrorism. The dimensions of terrorism occursnot only within the national borders of the states of origin or domiciliation of terrorist groups, but also across-boarders,regionally and globally. The impact of Terrorist activities could be localised, domestic, transnational and or global in nature.

Terrorists of all convictions have freely adopted any means considered suitable to their resource base, finances and capable of reaching their choice target. These means include a mix of violence in the form of assassinations, bombings, arson, hostage-taking, hijacking, kidnapping, sabotage, the perpetration of hoaxes and suicide bombings, fabrication and use of dirty bombs, attacking nuclear reactors, high-tech cyberattacks, ecological terrorism (for instance, the threat of destruction to the environment) and terrorist attacks aimed at destroying cultural heritage, as perpetrated by ISIL.

There has been a lot of concern on the issue of terrorism and its possible impact on global peace and security. Africa has not been spared its share of wars and woes, economically and politically. Terrorism and terrorist actions are also said to have had its toll on the continent. Much as the instances of terrorist acts are reported, it is useful toexamine the origins of terrorist groups, rationalisationfor involvement, motivating factors and the incidents of terrorism. Sandler (2014) survey article identified some major research interests asanalyses of terrorist attack trends; the economic effects of terrorism; the study of counter-terrorism effectiveness; causes of terrorist acts andhow terrorism and liberal democracies relate (Sandler, 2014). Terrorist activities especially those of the Al-Shabaab have 
Volume 8 Issue 3 March 2020

posed some global security concerns especially in Somalia and other neighbouring countries and efforts to contain their activities have too far to be realised.

It is on this premise that that this study is set address the concerns of motivating factors, trends of attacks and the economic and security implications of Al-Shabaab activities in Somalia and other neighboring African countries with a view to containing the menance to not only achieve regional but global peace and security. Specifically, this paper sets tomaaddress the following research questions:

(i) What is the motivation for the formation of Al Shabaaband the resort to terrorism?

(ii) What are the trends of Al-Shabaab's terrorist attacksin Somalia and other neighbouring countries?;

(iii) What are the economic and security implications of Al-Shabaabactivities on Somalia and its neigbours?

(iv) What can be done to contain the activities of Al-Shababb and restore security in Somali and other neigbouring countries?

\subsection{Literature Review}

\subsection{Concept of Terrorism}

Schmid (2004) notes that "terrorism has been situated - and thereby implicitly alsodefined -in various contexts such as crime, politics, war, propagandaand religion".He maintains that some aspects of terrorism are usually exposed while othersare not when a framework is in use.This depends, however, on the framework that is chosen afterall. He identified and reviewed five frameworks for conceptualising terrorism which include:

(1) Terrorism as Crime. This is terrorism expressed as violence. This will include assassinations, kidnapping, hostage-taking, armed attacks on civilian targets and hijacking;

(2) Terrorism and Politics. The use of terrorism as an instrument in form of political conflicts;

(3) Terrorism and Warfare.Terrorism as an act of war;

(4) Terrorism as/and Communication. Terrorism as a propaganda tool, to spread the message of a group;

(5) Terrorism as/and Religion.The use of terrorism as an instrument for achieving religious objectives or conception of terrorism as an expression of religious obligation. This presents terrorism with the garb of acceptance to justify the evil dead and placate the conscience, by making the act look like a sacrifice for a noble cause.

Chen, Reid, Sinai, Silk andGanor(2008) note that research on terrorism and related issues has increased dramatically since the occurrence of the $9 / 11$ attacks on the US. This is not unforeseen as the 
Volume 8 Issue 3 March 2020

9/11 witnessed the most destructive terrorist assaults inhuman history, and the attacks led to far bloodier conflicts as part of the subsequent war on terror. Terrorismhas been on the front burner of global discourse in contemporary times. Watkins (2015) posits that with the devastating effects of terror groups in Africa and the world at large, it becomes necessary to study their operations to support earlier studies. Njoku, Okeniyi, Ayara andAkoth(2018) posit that Kenya has suffered severe attacks along the eastern fringes of the country plausibly due to the presence of Kenya's military in Somalia and the use of Kenya's beautiful coastal beaches for tourism that is at odds with the Islamic culture and Kenya's closeness with the west which they see as antithetical to their bid to establish their brand of Islam in the Somalia and the region.

Ackerman (2014) notesthat terrorism across the African continent can be seen in two lights: the 'direct costs' in terms of damage to infrastructure, and the 'indirect costs' in terms of withdrawal of investments and decline in tourism through global image problem. Smith (2018) states that:

at the individual level, the radicalization process often involves embracing a terrorist belief system or narrative that identifies particular others or groups as "enemies" and justifies engaging in violence against them. Individuals may also begin to identify themselves as terrorists, as well as to engage in activities that highlight their commitments to their new beliefs, identities, and/or others who hold them.It is,however, important to note that while these beliefs and behaviors may facilitate the movement to terrorism, this outcome is not inevitable.(p. i)

Sandler (2014) is of the view that sets of data on terrorism only go back to 1968 , and show that there are specific cycles.Kamal(2008) notes that:

Terrorism induces intimidation, as long as it is a terrorist act, through the useof violence. Terrorism maintains itself in its essence only if it keeps or overtakes theterror level it has attained. The level of the terror attained by inducing intimidation isnot for the sake of recognition, like in the case of the fight between the master andthe slave in Hegel's The Phenomenology of Mind. A terrorist self does not intend tosubjugate the other for the sake of objective recognition and certainty of its ownindependence. It does not seek or need recognition because it is certain about itsown absolute freedom and values. But it intends to confirm the objective certaintyof its absolute freedom by destroying the existence of the other, which is 'same' likethe self but not identical to it. According to this analysis, the essence of terrorism is 'annihilation'. The aim of terrorism is not to subjugate but to annihilate the other. Annihilation is the negation of the independence of the other as well as total destruction of its existence. It is an action through which the other is not reduced to a 'thing' but transformed from the state of existence to non-existence. The recognised self reduces the recognising self to a mere object, while a terrorist self reduces this other to 'nothing'. (p.7)

The United Nations Ad-Hoc Committee on Terrorism seesterrorism the context of any act that causes death of someone or bodily injury or damages public or private properties. This definition focusses on the 'offence' character of terrorism and, clearly uses a crime perspective.For its part, the former Organization of African Unity (OAU) now African Union (AU) Convention on the Prevention and Combating of Terrorism (1994) also sees terrorism in the same context as that of the United Nations. 
Volume 8 Issue 3 March 2020

For instance, any acts carried out in violation of criminal laws of a State capable of endangering the lives of the anyone or properties whether private or public, are deemed as terrorism.

Ohuoha andEzirim (2013) view terrorism as the premeditated use of threat or use of violence by an individual or group to cause fear, destruction or death, especially against unarmed targets, property or infrastructure in a state, intended to compel those in authority to respond to the demands and expectations of the individual or group behind such violent acts. The demands and expectations of terrorists may be for a change in status quo in terms of the political, economic, ideological, religious or social order within the affected state or for a change in the (in)actions or policies of the affected state in relation to its interaction with (an)other group(s) or states. The mutual theme across all the several possible meanings of terrorism is political motivation. However, there is another trend which appears to be of even greater motivation for numerous terrorist organizations the world over: religious motivation.

Beck (2008) posits that no matter what ones' perspective, in defining terrorism, it is reasonable to suggest that terrorism includes: (1) violence or the threat of violence; (2) unconventional targets (e.g. civilians); and (3) political goals or political claim making. This position brings out what constitutes some of the essential components of terrorism. Sandler (2014) provides a classification or delineation of terrorist acts based on the origin of the perpetrator, the target and victim of the act, and notes that for a domestic terrorist incident, the three key agents - the perpetrators, victims, and targets - are all from the venue country.

From the above it can be deduced that terrorism is thusany plan or action which resorts to violent means, in violation of the laws of the country or international norms of conventions for conducting war, such as bombing, kidnaping, hijacking and other forms of violence on any target as a means of achieving or enhancing ones social group interest or as a response to perceived or real frustration to the achievement of a group's goal. This implies that individuals acting on their own, without a group are not classified as terrorists, hence their acts are not acts of terrorism. To be classified as terrorism, it must be actions or plans within the umbrella of a group.

\subsection{Concept of Global Security}

Sotirovic (2017) notes that global security as a concept has to be essentially founded on the idea of human security. As has been argued by Thomas Hobbes, the right to self-preservation is founded on a natural law, requiring at the same time a social harmony between the citizens and state authority. In this regard, global security has to be founded primarily on the security of the (nation) state as the natural form of political associations by the people. States in pursuit of their individual security enter 
Volume 8 Issue 3 March 2020

into arrangemenst with other states and give birth to the concept of Collective Security (CS) where states agree on formalized prcesses to protect members of the group. They support, help and defend fellow member states against external aggression.Indeed, the literature shows that global security has been greatly evolved from what we knew it to be for a long time in the past.

Mansbach (2012) states that the focus of security rests squarely on the humans instead of the state as the latter protects the humans and their properties.Hough(2008) details three Possible Models of Global Security model which are Unipolar, Bipolar or Multipolar. Unipolar Security Model (USM) assumes one dominant power (state) having the role of a global hegemon or world policeman responsible for keeping the peace. The Bipolar Security Model (BSM) has two crucial powers in the world checkmating each other to provide global security. The Multipolar Security Model (MSM) concieves of more than two locus of power. Osisanya (2014) contends that there is an attempt to create a division between national security and global security and this is largely in theory, but in actuality, it is diffcultto maintain a separation between both since they have a symbiotic relationship. There are security aspects that states cannot effectively handleunilaterallyalthough they fall initially within domestic boundaries. Conversely, therefore, there are security isues at the global/international level that can be best addressed through actions at the domesticlevel.Bill (1999) opines that global security evolved from obligations which activities such as globalisation have placed on states. They are demands that individual state security apparatuses do nothave capacity to handle on their own hence they require cooperation among states, due to global interconnection and interdependence among states

Jackson (2011) notes there are three main paradigms of security within international relations: national security, international security and human security. The national and international perspective gives moral primacy to the state as a necessary precondition for human flourishing, while the human security perspective gives moral primacy to human beings and the community of humankind over and above the interests of states or the international society to which they belong. In the realist perspective the state is responsible to both define, provide and protect security, through the use of its laws, resources and institutions. This means expressly that the state has the responsibility to deal with any threat to security which include criminality, rebellion, terrorism, and other forms of lawlessness. On the other hand, the international perspective does not put the obligation for security squarely on states alone, but extends to the international comminity. They recognise actors in the security schematic beyond the individual state actors; they include bilateral and multi-lateral institutions set up my states to address common objectives. International or global security is thus a challenge for the international society as a whole. 


\subsection{Theoretical Framework}

This study adopted Social Identity Theory as theoretical framework in view of the nature of this study especially taking into cognisance the fact that the trends of Al-Shabaab's activities in Somalia and other neighbouring African countries are a reflection of a group's identity and interest. And there is no doubt that that this theory is suitable to a study like this.

In his contributions to the Social Identity Theory,David (2015) notes thatTajfel (1979) described Social Identity as a person's sense of who he or she is, based on their group membership(s).In order to increase our self-image we enhance the status of the group to which we belong. Therefore, the world is divided into "them" and "us" by way social categorisation - in-group and out-group. Social identity theory holds that the in-group will usually discriminate against the out-group by way of finding faults against the latterwith a view to enhancing their reputations. This orientation ofin and out group leads to a sense of hatred, efforts to eliminate the out group through any form or means which could include rejection of the out group, acts of violence and attacks against the out group, terrorist acts etc.

Tajfel(1979) cited in David (2015) posits that stereotyping which involves getting people into categorised groups is usually done on a normal cognitive process.Tajfel \& Turner (1979) proposed three mental processes used in evaluating 'in-group' and 'out-group' - categorisation, social stratification and social comparison. Thus, within this framework,Al-Shabaab seeks to extend their interest and confront oppositions. They would resort to any means to address their ideas against the 'out group'.

It is rife in human experience that members of a group desire to live the ideals of the group, defend its ethos and values such that they can be properly recognized as belonging to the group. The logical consequences of belonging to group include the exhibition of the values of that group to compete with rivals in a bid to project our group. There is energy to outdo the other group because continued sensitization towards the in group moulds the consciousness of the group members from merely being members of a group but inculcates the consciousness of "a group for itself". This is the state of being mobile for the cause of the group as defined by the appropriate persons or sources. Logically, members of the ingroup discriminate against members of the out group.

So, Al-Shabaab discriminates against Christians, other non-Moslems, and Moslems of a different persuasion.The membership of groups hasdefinite consequences on individual perceptions and behaviour. When individuals belong to a group, they begin to think in the group mode. They jettison 
Volume 8 Issue 3 March 2020

individual thought patterns and take on the group thought pattern as the group attains a higher relevance for them as against their personal goals. They now think group and act group. This is exactly the scenario with the Al-Shabaab terrorist activities in Somalia and otheneighboring Africa countries which has been become a threat to global security. Therefore, Social Identity Theory has become very expedient in studying the activities of Al-Shabaab and its dire consequences on the overall global security architecture with a vioew to identifying stern measures to address the age-long cankerworm eating deep into global peace and security.

\subsection{Terrorism and Global Security -ALShabaab in focus, 2015-2018}

\subsection{The origin of Al-Shabaab}

Harakat al-Shabaab al-Mujahideen, more commonly known as Al-Shabaab or Al-Shabab (ال شد باب) ash-Shabāb)is an Al-Qaeda-affiliated organisation that has risen rapidly to prominence in the midst of Somalia's decades-long anarchy.Al-Shabaab is an Arabic phrase meaning "the Youth". This group known as al-Shabaab, meaning 'the youth' and it was headed by al-Qaeda trained Somalianoperative in Afghanistan by name - Aden Hashi Farah/Ayro. Al-Shabaab took a more extreme stance than the Islamic Court Union (ICU) as a whole, espousing a puritanical version of Islam at odds with the Sufi-influenced form practised by many Somalis.Masters\&Sergie(2015) posit that Al-Shabaab emerged as an independent organization around December 2006 after breaking away from the Islamic Courts Union (ICU) for which it had served as the military wing when they controlled Mogadishu in 2006, before being forced out by Ethiopian forces.

The $18^{\text {th }}$ Century Muslim reformer set the scene for the emergence of Al-Shabaab. He was of the view that Islam had been corrupted after the death of Prophet Mohammad and sought something of a renaissance for Islam through an adoption of a brand of Islam with a distinct interpretation and dogma.This cradle for the organisation defined the location and emergence of a distinct social group founded on a separateness based on religious interpretations and beliefs. They saw their religious standards as being compromised and found for themselves a messianic role for their faith. They see those who are sympathetic to their perspectives of Islam as in-group while those who did not share their belief as out-group. This out group ranges from fellow Muslims outside the Wahabbi tradition, Christians and other religious convictions. There was a clear in-group consciousness whichmoulded their orientation. This reality justifies the explanation of the formation and recruitment drive by the organisation with reference to the social group theory, and their various actions to undo the out group.

\subsection{Al-Shabaab's Ideology}

Al-Shabaab's ideology is based on three Precepts (1) Establishment of Islamic State (2)Implementation of Sharia law (3) Jihad against the West and Foreign Intervener. The establishment 
Volume 8 Issue 3 March 2020

of Islamic State in Somalia is undoubtedly the main political ideology of the organisation. The strategy is to establish an Islamic state first in Somalia then gradually move to the other parts of the Horn of Africa.Ali (2008) notes that, initially, Al-Shabaab pursued the establishment of an Islamic Emirate in Somalia including the north-eastern region of Kenya, the Ogaden region of Ethiopia as well as Djibouti. According to Moll \& Livermore (2010),it on record that trainings AlShabaabconducts for its members are usually tailored towards establishing an Islamic state. Harnisch (2010)opines that the Al-Shabaab American Commander, Omar Hammami (Abu Mansour al Amriki) defined the group's aim as global: "Al-Shabaab had a global goal including the establishment of the Islamic Caliphate in all parts of the world". EstablishingIslamic State was in consonance with AlShabaab's partners in crime - Al-Qaeda.These statements from the leaders of Al-Shabaab demonstrate the recognition of themselves as a group and the operation as a group with clear recognition of boundary lines that separate them and their members from all others. It also justifies their aggressive actions against others whom they see as standing in the way of their objectives.

Regarding the implementation of Sharia law, Al-Shabaab has imposed a strict version of Sharia law. Al-Shabaab's sternness of Sharia rulings can be viewed in the eyes of the laws that it executed and andpunitive measures meted out. Shinn(2009) notes that one of its (Al-Shabaab) goals is the implementation of a draconian version of sharia, although actual Sharia rulings seem to vary from one Al-Shabaab controlled part of Somalia to another. All these have involved all manner of crimes such ascutting of heads,killing of adulterers with stones, and amputations of suspected criminals. Reuters (2009) reports that residents in Marka complained that Al-Shabaab has been rounding up anyone seen with silver or gold tooth and taking them to a masked man who then rips them out using basic tools. Foreign Service (2009) reportedthat Al-Shabaab went after women in the streets of Mogadishu for wearing bras as they claimed violated Islam. The women who appeared with firm bust were examined to determine if it was natural or bra wearing. Any anti-Islamic forms of culture and entertainment are banned.Camphausen (2010) observes that Al-Shabbab rules like the Afghan Taliban as they have completely subjugated the entire population to an extreme version of the Sharia.

Logically, the third realm of Al-Shabaab's philosophy which is Jihad against the West and Foreignerswas to distance them from the territory referred to as Islamic and needing no stranger elements within. Al-Shabaab attempted to get rid of the foreigners and outside influences from the country, who they see as enemies to their declared intension to set up an Islamic state. Al-Sabaab has its targets outside Somalia with keen resolve to attack the interests of western nations. According to Sheikh Mukhtar Roobow, al-Shabaab's spokesman and spiritual leader, "terrorizing non-Muslims who come to your land is a religious obligation". Since then, Al-Shabaab targeted Western interests both inside and outside Somalia. 


\subsection{Al-Shabaab and Global Security,2015- 2018}

Al-Shabaab's notoriety stems from among otherstheir declaration of allegiance to Al Qaeda in 2012 and the gradual but sustained spread outside of Somalia, creating problems for US backed nations such as Kenya and Ethiopia, as well as the Western world. On March 2018 the United States of America designated two Al-Shabaab top leaders. Al-Shabaab is banned as a terrorist group by both the US and the UK and is believed to have between 7,000 and 9,000 fighters.

In the African region, Al-Shabaab has organized, carried out and claimed responsibility for many terrorist acts like bombing, road block, forced taxation, beheadings, stoning etc, which have adversely affected the security of Somali, Kenya, and other neighbouring countries while their activities have also had international and global implications as they delved into piracy and arms.

\subsection{Samples of Al-Shabaab attacks}

BBC (2010) had said that the group launched an attack for the first time outside Somalia when it bombedKampala in Uganda in July 2010. This attack claimed more than 74 lives, including an American aid workeramongst those who gathered in Kampala, Uganda, to watch a screening of a World Cup football (soccer) game. Al-Shabaab claimed the attack as retaliation for Ugandan troops' participation in The African Union Mission in Somalia (AMISOM).

Al-Shabaabwas responsiblefor the Westgate Mall bombing which occurred in Kenya's capitol, Nairobi, when militants killed 62 people. Al-Shabaabhas spread its recruitment net such that internationally it poses a major threat to security as a breeding ground for terrorists. Al Shabaab is no longer a grassroots organisation.

Al-Shabab had battled the UN-backed government in Somaliaand including plethora of attacks in many parts of the region. It is also a known fact that Al-Shabaab leadership urged its followers to attack Israel. Al-Shabaabwas said to have, in November 2009, put together a new military outfit codenamedAl-Quds Brigade in a bidto lunch unprecendentedattacks on Israel and release Islamic holy places. Al-Shabaabtook a battle against Israel in an effort toeliminatethe Zionist and Jewish interests in Africa. Al-Shabaab attracted international condemnation for the ban and restriction of international aids from donor agencies in Southern Somalia at time deadly drought and famine came calling in 2011.

Between 2015 and 2018, the world witnessed continued terrorist offensive by Al-Shabaab. The group struck Kenya again, on $2^{\text {nd }}$ April, 2015, terminating the lives of over 147 persons as many were injured 
Volume 8 Issue 3 March 2020

when it raided a university college in Garissa, Kenya. The group's spokespersonsaid the rampage was a retribution for non-Muslims taking over Muslim areas.

In June 2018, Al-Shababowned up an attack on a soldier belonging to a U.S. special operations forces.In Al-Shabaab's surprise attack on the Central Hotel in Mogadishu, twenty (20)persons werekilled including the local deputy mayor and a legislator.

The organisation used publicity effectivelyby releasing a propaganda video calling for a lone wolf attack on the Mall of America in Bloomington, Minnesota, the West Edmonton Mall in Alberta, Canada and other Western shopping centers.Al-Shabaab insurgents attacked the Hotel Maka Al Mukaram in Mogadishu. After a car laden with explosives detonated, five armed militants penetrated the grounds. Among others, the Somalia Ambassador to the UN Human Rights Office in Geneva, Yusuf Mohamed Ismael Bari Bari was killed. The Injured include around 20 wounded soldiers, state officials and hotel personnel.The security forces also succeeded in rescuing over 50 hotel guests, including a Somalia Ambassador. A suicide car bomb detonated at the gate of the Ministry of Higher Education and Ministry of Petroleum and Resources building in Mogadishu. Militants planted a bomb in a UN van in the northeastern city of Garowe. According to police Colonel, Ali Salad, at least seven workers are killed in the ensuing blast. Four-individuals were also injured as Al-Shabaab later claimed responsibility for the attack through its radio station. There was the Leego attack - AlShabaab militants attacked an AMISOM base with a car bomb.Al-Shabaab's spokesman for military operations, Sheikh Abdiasis Abu Musab said that the group was responsible for carrying out two attacks in Mogadishu that resulted in the gunmen killing a lawmaker, Abdullahi Hussein and his bodyguard as well as an official from the Prime Minister's office.

Al-Shabaab claimed responsibility for the failed suicide bombing of Daallo Airlines Flight 159, which occurred on February 2, 2015. The group stated that they originally intended to attack a Turkish Airlines Flight and that they were targeting Western intelligence officials and Turkish NATO soldiers who were on board.

Al-Shabab has continued to conduct attacks both within Somalia and in neighboring Kenya, including a January 15, 2019 attack on an upscale Nairobi hotel complex in which at least twenty-one civilians were killed and hundreds held hostage.In response to the 2011 intervention, Al-Shabab has committed more than 150 attacks in Kenya, a long-time U.S. ally. The most brutal were a January 2016 attack on a Kenyan army camp in El Adde killing 200 soldiers. In the 2015 assault at Garissa University in northeast Kenya they killed 148 people.Four gunmen from the al-Qaeda-affiliated Islamist group rampaged through Garissa University on April 2, 2015, before being killed by security forces the same day.The Dusit attack at 14 Riverside Drive began shortly before 1530 hours onJanuary 15, 2019, when one of the terrorists entered the compoundand positioned himself in a grassy space outside the 
Volume 8 Issue 3 March 2020

Secret Gardenrestaurant. On 4 February 2019, at least 11 people were killed and 10 others injured in a car bombing attack at a shopping mall in Mogadishu, Somalia.

These examples of Al Shabaab's terrorist activities within the period in reviewdemonstrate the negative impact of the activities of the organisation on the politics and economy of Somalia and other neigbouring countries. It is clearfrom the above, that Al-Shabaab's sustained terrorist activities have brought a regime of fear, maiming, food insecurity into Somali and her neighbouring countries and territories. The organization in a bid to sustain itself sought and expanded economic and financial channels. This has led to a tightening of its grip and widening of its activities in vital economic centres of the region. CNN(2018) in Baidoa, Somalia CNN investigation revealed that aid money sent to Somalia by western nations to eliminate the terror group ends in the very hands of Al-Shabaab. In addition, they extorted taxes, mounted road blocks and collected payments from merchants attempting to transport food and supplies to sell to internally displaced people in towns where they are concentrated. They either seized food convoys or collected payments from them before they could be allowed to journey through. It is reported that Aid Organizations were so desperate to help that they paid warlords to permit access to starving victims.

Kambere (2012) states that, as with all organizations, financial channels are the hidden arteries that keep Al-Shabaab alive. Al-Shabaab has leaned on different sources of revenue to finance terrorist acts for the past several years, including state sponsors, charities, individuals in the Somali diaspora, other terrorist groups, and businesses. The money goes mainly to support the group's members, and for the training, recruiting, weapons, and equipment required to sustain the Somali insurgency and wage jihad against non-believers. Al-Shabaab has maintained a stranglehold on the economy of the region and beyond through forced donations from Charities and Donations from other Terrorist Organizations.Funds from Diaspora, Black markets in places like Eastleigh, a Somali immigrant neighborhood in Nairobi, raised reasonable large sums of money to support the group's activities. They imposed Zakat, an Islamic religious tithe and tariffs from Informal Islamic banking andBusinesses in the Port of Kismayo. The group imposed harsh administrative rules based in sharia law on the port's business community to raise revenue. Importing and exporting fees were imposed on goods like rice from Pakistan, and the export of primary goods such as livestock (camels, sheep, and goats), charcoal, and khat to the Gulf states.It is estimated by one analyst for African affairs that the taxes Al-Shabaab collects from the business community in Kismayo include "over $\$ 1$ million quarterly in port-use charges alone".Pijovic (2014) identifies other sources of funding to include revenues from the Charcoal Industry, which isone of Somalia's main exports, and the chief commodity to pass through Kismayo's port facilities. To sustain this source of finance, they encouraged the cutting down of trees, and this has painted the landscape withVast deforestation in the 
Volume 8 Issue 3 March 2020

areas under Al-Shabaab's control. It is estimated that Al-Shabaab exports charcoal worth $\$ 500,000$ per month to the Gulf states and extortion of farmers which has led to a decrease in agricultural production.Masters \&Sergie (2015) assertthat the United Nations believes that al Shabaab collects an estimated U.S. \$35-50 million annually in custom tolls and taxes on businesses in Kismayo and two secondary ports higher up the coast.Abdiraham (2010) said that this is one reason that Kismayo is referred to as the nerve center for the terrorists. The funds generated is used to sustain their activities. Other sources are collections from Coastal Fishing towns, Piracy and Extortion. The group's cooperation with pirates operating in the Gulf of Aden and Indian Ocean remains a source of its income from Somali pirate groups, but it had been difficult to establish a direct connection between the Islamists and pirates and the looting of the nongovernmental organizations (NGOs) that are operating in areas controlled by Al-Shabaab, business profits, security protection fees from prominent business people and aid workers.

Kambere (2012) affirms thatAl Shabaab spends most of its money on four things: (a) providing social services to its members (including paying salaries to foreign fighters); (b) fighting to overthrow Somalia's Transitional Government and to expel Ethiopian troops from Somali territory; (c) waging a violent campaign against nonbelievers (jihad), which includes recruiting and training fighters and buying weapons and equipment; and (d) preaching extremism. Al-Shabaaboperatives are said to often carry cash on their missions of bombings by crossing into Uganda even with extra funds.

\subsection{Summary, Conclusion and Recommendations}

\subsection{Summary}

This study of Al-Shabaab has demonstrated that the terrorist activities of the organization has caused huge damage to the people of Somali and their neigbouring countries like Kenya, Ethiopia etc. The impact of their activities has produced death and destruction, exacerbated hunger and starvation in the region, the citizenry lack food security, nutrition levels have dropped. They have created a psychology and culture of violence in the younger generations who have been recruited into the organisation. The economy of the countries have been pillaged by mindless terrorists, the women and children have had their psyche invaded by mindless terror.

In terms of personal security, the people of Somalia especially and other targeted locations have had to live under a regime of fear and intimidation. The rights of the people have been systematically and humiliatingly violated. The dignity of women have been violated, their husbands killed, children witnessed the massacre of their parents as terror is unleashed on the streets. Since its inception, the organization has forced their brand of Islam on others, meaning a violation of the people's right to worship and choice.They have fought to destabilize the legitimate regimes in Somalia, attacked Aid 
Volume 8 Issue 3 March 2020

workers,prevented humanitarian activities by the United Nations. Their involvement in the economic activities of Somalia has dislocated its economy. Because of fear and insecurity agricultural and industrial production have become practically non-existent. Somalia has become synonymous with uncertainty, violence, terror and death.

The taxes and other forms of forced financial extractions by the organization are huge leakages to the resources needed to develop the country. Thus, underdevelopment is a constant indices of Somalia.Somalia is almost a failed state. Transparency International's 2017 Corruption Perceptions Index ranks Somalia as the world's most corrupt country. For several years, the economy is plagued, dependent on foreign aid and lacks a productive economy, all credited to Al-Shabaab activities. No doubt, as evidenced by its activities, Al-Shabaab is still a very viable and potent terrorist organization. It has survived threats to its existence by being creative and indeed resilient, secured its sources of finance through taxes and demonstrated growing capability to carry out attacks.

\subsection{Conclusion}

There is no gainsaying the fact that terrorism has a huge cost on society. This include emotional, social, economic and political. The costs are both direct and indirect. Terrorism affects the current businesses and diminishes the prospect for future businesses. The incidence of terrorism has impacts at the micro and macro levels of the economy and social life in the affected areas. When terrorist activities become widespread, economic life is adversely impacted. Investors take their capital out of terror afflicted areas to safer countries. Foreign investors are usually dissuaded due to increased risk of doing business likewise local ones. There is a huge fund requirements for restoring damaged structures, social disharmony due to loss of lives, medical emergencies and expenditure to treat injuries sustainedand reduced commerce. The cost of insurance and security increases either doubly or triply. Gross Domestic Product (GDP) is affected as well as growth potentials for the economy.Due to the impact of terrorism, investors are very likely to move their funds to other safer locations,. All these have been the cae of Somalia and other neighbouring countries of Africa since the inception of Al-Shabaab and its terrorist activities in the region. We, therefore, conclude that except stern measures are taking to stem the tide of Al-Shabaab's terrorist activities in Somalia and other neighboring African countries, the efforts by all and sundry to achieve global peace and security, would be an exercise in futility.

\subsection{Recommendations}

Terrorismhas been a global menace, more so, with the affiliation of local groups with international groups like ISIS and Al-Qaeda. No single country can go it all alone. To effectively manage the scourge, what is required is action at a trans-national level. This will require sharing of intelligence 
Volume 8 Issue 3 March 2020

between security organizations across borders. There also need for constructive engagements with the populace in the affected areas to sensitize them on the ills of association and/or participation in terrorist activities. There is the need for governments to address economic hardship which predisposes potential recruits. Real injustices need to be addressed where they exist. On a global scale, there needs to be collective action to curtail and eliminate religious extremism. Arms control legislations and enforcements need to be more effective to prevent the indiscriminate sales of arms to terrorist groups, while there should bemore international collaborations to trace and block sources of funds for terrorist organizations. Through more effective and aggressive policing of border areas, Al-Shabaab's activities can be significantly curbed to achieve regional and global peace and security.

\section{References}

Abbasi, I.A. \&Khatwani, M.K. (2018). A Review of Psycho-Social Theories of Terrorism.Grassroots, 51(1).

Abdiraham, A.( 2010). "Teenage Al-Shabaab Soldiers in Training," Demotix News, October 29:Ngirachu, "Al-Shabaab Militia's Tight Grip.

Retrieved September 30, 2019 from http://www.demotix.com/news/495081/teenage-alshabaab-soldiers-training.

Ackerman, D.G. (2014). "The rise of radical Islamic terrorism in Africa: State collapse vs. State dysfunction". Thesis for the degree of Masters by research for Bachelor of Arts in the International relations, submitted to the University of the Witwatersrand.

Ali, A.M. (2008). The Al-Shabaab Al-Mujahidiin:A Profile of the First Somali Terrorist Organization. InstitutfürStrategiePolitikSicherheits und Wirtschaftsberatung (ISPSW), Berlin,Germany.

Beck,C.J. (2008). The Contribution of Social Movement Theory to Understanding Terrorism. Sociology Compass, 2(5),1565-1581.

Bill, M. (1999). Security, Identity and Interests: A Sociology of International Relations, Cambridge: University Press.

Breuer, J., \& Elson, M. (2016). The frustration-aggression hypothesis according to Berkowitz (1989).Figshare. doi:10.6084/m9.figshare.4224270.v2

Breuer, J.\&Elson, M.(2017). Frustration-Aggression Theory DOI:10.1002/9781119057574.whbva040

Camphausen, R.C. (2010). Sharia in Somalia: Al-Shabaab rules just like the Afghan Taliban, August 2010. Retrieved September 30, 2019 from http://www.digitaljournal.com/article/296400\#ixzz10W3clzbz'

Chadwick, E. (1996).Terrorism and the law: Historical contexts, contemporary dilemmas, and the end(s) of democracy.Crime, Law and Social Changes, 26(4), 329-350.

Chen, H., Reid, E., Sinai, J., Silke, A. \&Ganor, B. (Eds.) (2008). Terrorism informatics 
Volume 8 Issue 3 March 2020

knowledge management and data mining for Homeland Security. New York, USA: Springer.

Cohen, A. R. (1955). Social norms, arbitrariness of frustration, and status of the agent of frustration inthe frustration-aggression hypothesis. Journal of Abnormal and Social Psychology, 51(2), 222-226.doi:10.1037/h0039947.

Crenshaw, M. (1981).The Causes of Terrorism.Comparative Politics, 3(4), 379-399. Available from http://courses.kvasaheim.com /hist319a/docs/Crenshaw\%201981.PDF. Accessed 2 September, 2015.

Da Gloria, J. (1984). Frustration, aggression, and the sense of justice. In A. Mummendey (Ed.), SocialPsychology of Aggression: From individual behavior to social interaction(pp. 127-141). Berlin,Germany: Springer.

David, L. (2015). Social Identity Theory (Tajfel, Turner). Learning Theories.Retrieved September 30, 2019 from https://www.learning-theories.com/social-identitytheory-tajfel-turner.html

Dollard, J., Miller, N.E., Doob, L.W., Mowrer, O.H., \& Sears, R.R. (1939). Frustration and aggression. New Haven, CT: Yale University Press.

Friedlander, R.A. (1976). The Origins of International Terrorism: A Micro Legal- Historical Perspective.Israel Yearbook on Human Rights, 6, 40-49.

Gurr, T. (1970). Why men rebel. Princeton, NJ: Princeton University Press.

Harnisch, C.Z. K. (2010, February 12). The Terror Threat from Somalia: The Internalization of Al-Shabaab. A Report by Critical Threats Project of the America Enterprise Institute.

Hough, P. ( 2008).Understanding Global Security (2 ${ }^{\text {nd }}$ ed.). London \&New York: Routledge.

International Crisis Group. (2014). “Somalia: Al-Shabaab-It will be a Long War”, June 26, 2014. Retrieved September 30, 2019 fromhttp://www.crisisgroup.org/ /media/Files/africa/horn-of-africa/somalia/b099-somalia-alshabaab-it-will-be-a-long-war.pdf

Jackson, P. (2011).Security in International Relations. London: University of London Retrieved September 30, 2019 from www.londoninternational.ac.uk

Jenkins, B.M. (2001). Terrorism and Beyond: a 21st Century Perspective.Studies in Conflict \& Terrorism,24(5), 321-27.

Johannes, B.J.\& Elson, M. (2017). Frustration-Aggression Theory. Retrieved September 30, 2019. DOI: 10.1002/9781119057574.whbva040University of Cologne, Germany Malte Elson Ruhr UniversityBochum, Germany.

Kamal, M. (2008). Meaning of Terrorism: A Philosophical Inquiry. Asia Institute National Centre of Excellence for Islamic Studies NCEIS Research Paper, 1(1).

Kambere,(2012). UPDF Financing Al Shabaab: The Vital Port of Kismayo August 2012.

Retrieved September 30, 2019 from https://globalecco.org/financing-al-shabaab-the-vitalport-of-kismayo/-

/journal_content/56_INSTANCE_DsOuVYb6TvzU/10180/611478;jsessionid=299F25E31B8 
Volume 8 Issue 3 March 2020 D9A4ABDF02CD189514C6E?p_p_state=pop_up\&_56_INSTANCE_DsOuVYb6TvzU_vie $\underline{\text { wMode }=\text { print }}$

Khalif, A.K. (2009, September 19). Defiant Al-Shaabab reaches out to Somalis in Diaspora. Daily Nation.

Kohlmann,E.F. (2009). Migration and Jihad in The Horn of Africa. Retrieved September 30, 2019 from www.nefafoundation.org

Masters, J., \&Sergie.A.M. (2015). “Al-Shabab”.Council on Foreign Relations. (Last modified March,13, 2015). Retieved September 30, 2019 fromhttp://www.cfr.org/somalia/alshabab/p18650.

Miller, N. E., Sears, R. R., Mowrer, O. H., Doob, L. W., \& Dollard, J. (1941). The frustrationaggressionhypothesis. Psychological Review, 48(4), 337-342.

doi:10.1037/h0055861

Morlan, G. K. (1949). A note on the frustration-aggression theories of Dollard and his associates. Psychological Review, 56(1), 1-8. doi:10.1037/h0056948

Njoku, C.G. Okeniyi, O.O., Ayara, N.N. \&Akoth, C.O.( 2018). Terrorism in Africa: $\quad$ Mapping the Nigeriaand Kenya situation. International Journal of Development and Sustainability, 7(3), 993-1014.Retrieved September 30, 2019 from www.isdsnet.com/ijds.

Onuoha, F. \&Ezirim, G. (2013). "Terrorism” and transnational organized crime in Western Africa, available http://studies.aljazeera.net/en/reports/2013/06/2013624102946689517.html, Accessed13 August, 2017.

Osisanya (2014) National Security versus Global Security UN Chronicle, The Magazine of TheUnitedNations, October 2014

https://unchronicle.un.org/article/national-security- versus-global-security

Osman, A. (2015).No Spring in Africa: How Sub-Saharan Africa Has Avoided the Arab Spring Phenomenon. Politics \&Policy, 43(5),754784 http://onlinelibrary.wiley.com/doi/10.1111/polp.12129/abstract

Pastore, N. (1950). A neglected factor in the frustration-aggression hypothesis: A comment. Journal of Psychology, 29(2), 271-279. doi:10.1080/00223980.1950.9916032

Pastore, N. (1952).The role of arbitrariness in the frustration-aggression hypothesis.Journal OfAbnormaland Social Psychology, 47(3), 728-731. doi:10.1037/h0060884

Paul, W. (1986).Terrorism and the Liberal State (Rev.Ed.). London: Frank Cass

Paul, S.Z. (2006). International Terrorism: Large-Scale Victimization Terrorism. In U. Ewald and K.Turković(Eds.),Large-Scale Victimisation as a Potential Source of Terrorist Activities. IOS Press

Pijovic, N. (2014).The sources of al-Shabaab's strength and resilience.National Security College at the Australian National University.

Pitts, D.E. (2015). New Destinations of Islamic Fundamental Terrorism: The Rise of AlShabaab. University of Tennessee - Knoxville. 
Richard, W., Mansbach, K. \&Taylor, L. (2012). Introduction to Global Politics(2nd ed.).

London \& New York: Routledge.

Sandler, T. (2014). The analytical study of terrorism: Taking stock Department of Economics, School of Economic, Political \& Policy Sciences, University of Texas at Dallas. Journal of Peace Research, 51(2), 257-271. The Author(s) 2013 Reprints and

Permission:sagepub.co.uk/journalsPermissions.nav DOI: $\quad 10.1177 / 0022343313491277$ jpr.sagepub.com

Schmid, A.P.(2004). Frameworks For Conceptualising Terrorism.Terrorism and Political Violence, 16(2), 197-221, DOI: 10.1080/09546550490483134

Shuriye, A.O. (2012). "Research: Al-shabaab's Leadership Hierarchy and its Ideology". Horn Affairs, May 7, 2012. Retrieved fromhttp://hornaffairs.com/en/2012/05/07/research- alshabaabs-leadership-hierarchy-

Smith, A.G. (2018). How Radicalization to Terrorism Occurs in the United States: What Research Sponsored by the National Institute of Justice Tells Us National Institute of Justice. U.S. Department of Justice Office of Justice Programs National Institute of Justice.

Sotirovic, V.B. (2017). Global Security: Is It Possible and How? The Global System of International Relations. Global Research Oriental Review, 29.

Stanford University. (2016). "Mapping Militant Organizations: Al Shabaab". Accessed September 30, 2019 from http://web.stanford.edu/group/mappingmilitants/cgibin/groups/view/61

Taarnby, M. \&Hallundbaek, L. (2010). Al-Shabaab: The Internationalization of Militant Islamism inSomalia and the Implications for Radicalization Processes in Europe. Retrieved September 30, 2019 fromwww.justitsministeriet.dk

Taarnby, M. \&Hallundbaek, L. (2007). The Internationalization of Militant Islamism in Somalia andthe Implications for Radicalization Processes in Europe, Ministry of Justice, 26 February.

Tajfel, H., Turner, J. C., Austin, W.G., \&Worchel, S. (1979). An integrative theory of intergroup conflict. Organizational Identity: A Reader, 56-65.

Thompson, R.J., \&Kolstoe, R.H. (1974). Physical aggression as a function of strength of frustrationand instrumentality of aggression. Journal of Research in Personality,7(4), 314323.doi:10.1016/0092-6566(74)90053-1

Thimm, J. (2018). From Exception to: The United States and the War on Terrorism. Stiftung Wissenschaft undPolitik German Institute for International and Security Affairs Johannes.

United Nations Security Council. (2011). "Report of the Monitoring Group on Somalia and Eritrea pursuant to Security Council resolution 1916". United Nations Security Council, July 18, 2011. Retrieved September 30, 2019 from http://www.un.org/ga/search/view doc.asp?symbol=S/2011/433 
Volume 8 Issue 3 March 2020

United Nations. (2009). Human Security Unit, United Nations Office for the Coordination of

Humanitarian Affairs. Human Security in Theory and Practice.

Retrieved September, 2019 from

http://hdr.undp.org/en/media/HS Handbook 2009.pdf

Watkins, E. (2015).LAPSSET: Terrorism in the pipeline? Counter terrorist trends and Analysis.Journal of the International Centre for Political Violence and Terrorism Research,7(8), 4-9.

Whittaker, D. (2001). The Terrorism Reader. London: Routledge

Yan, H.(2015). "What is Al-Shabaab, and what does it want?" CNN, April 2, 2015,

Retrieved from http://www.cnn.com/2015/04/02/world/africa/al-shabaab-explainer/

Ziemke, C.F. (2006). Perceived Operation and Relative Deprivation: Social Factor

Contributing to Terrorism. In McMillan, J. (Ed.). In the Same Light as

Slavery: Building a Global Antiterrorist Consensus. Washington DC: INSS

Books.

Zillmann, D. (1979). Hostility and aggression. Hillsdale, NJ: Erlbaum 